\title{
Analysis of Errors in the Phonetic Transcription of English Consonants by Egyptian Undergraduate Language Students
}

* Dr. Iman M. Mahfouz

\section{Abstract}

Raising learners' awareness of the target language phonology is one of the aims in foreign language teaching. Phonetic transcription has traditionally been used in language teaching particularly at advanced levels. This study examines the phonemic transcription of 30 English words by a number of 60 Egyptian learners studying an introductory phonetics course at undergraduate level.

It attempts to find out the errors made by students in transcribing English words involving consonants in particular. It also seeks to explain the reasons for these errors, with the aim of raising learners' awareness of them.

The study touches upon the deeper underlying structures involved in learning phonemic transcription. Identifying the most frequent errors in phonemic transcription by Egyptian learners of English can help place more emphasis on them in teaching, thus helping the learning process to be more successful.

Keywords: Error Analysis (EA) - phonemic transcription -transcription errors - Egyptian phonetics students

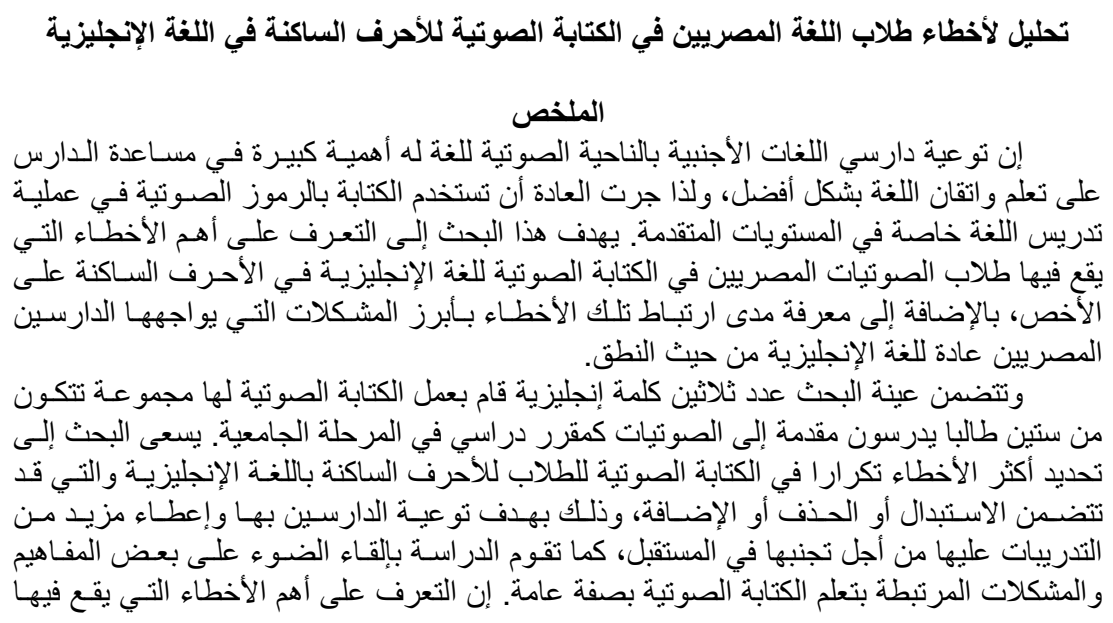

* Lecturer and Vice Dean for Education Affairs

College of Language and Communication (CLC)

Arab Academy for Science, Technology and Maritime Transport

(AASTMT) Alexandria 


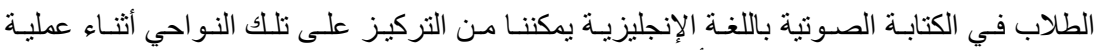
التدريس مما يؤدي إلى تلافي تللك الأخطاء في المستقبل و الارتقاء بعملية التعلم.

\section{Introduction}

Raising learners' awareness of the target language phonology is one of the aims in foreign language teaching. Phonetic transcription, which is defined by Wells (2006) as "the use of phonetic symbols to represent speech sounds" (p. 1), has traditionally been used in language teaching particularly at advanced levels. Two main types of transcription are distinguished: phonemic or broad transcription which captures distinctive aspects of phonemes and ignores details that do not affect word meaning, as opposed to phonetic or narrow transcription which provides more details of allophones and makes very subtle distinctions between sounds (Wells, 2006). For the purpose of the present study, phonemic transcription will be used for simplicity since students are more familiar with it at this introductory stage.

As Sönning (2013) states, "providing an unambiguous symbol-to-sound correspondence, transcription is particularly useful in the EFL context as English orthography and pronunciation diverge drastically" (p. 83). According to Lintunen (2005), phonetic transcription errors correlate to a large extent with learners' pronunciation errors. He also suggests that teaching phonetic transcription is particularly beneficial to learners whose first language (L1) is characterized by a close grapheme-phoneme relationship (see also Kuutti, 2009).

The relationship between spelling and pronunciation in English is not straightforward for Egyptian learners. Phonetic awareness is thus assumed 
to improve learners' pronunciation skills (Lintunen, 2005). Atkielski (2015) also suggests that phonetic transcription can be used prescriptively, to show students how a given word or phrase should be pronounced (2005). He maintains that "a student can often better understand his errors in pronunciation if he sees them laid out in static visual form" (p. 1). Sönning (2013), however, notes that courses of phonetics and phonology are unpopular among students who usually complain of their poor performance particularly in phonetic transcription which they consider a difficult task. Although the phonetic symbols might appear challenging at first, in a survey done by Lintunen (2004), 76.3\% students said that all the symbols were easy to understand and learn, whereas only $2.6 \%$ of the respondents claimed 9 that most of the symbols were difficult to understand.

There are 24 English consonants classified according to voicing, place and manner as shown in the table below with voiceless counterparts on the left and voiced ones on the right (Cruttenden,2014,p. 161).

Table 1: English consonant chart (Cruttenden, 2014)

\begin{tabular}{|c|c|c|c|c|c|}
\hline \multirow{2}{*}{$\begin{array}{c}\text { Manner of } \\
\text { articulation }\end{array}$} & \multicolumn{5}{|c|}{ Place of articulation } \\
\cline { 2 - 6 } & plosive & affricate & fricative & nasal & approximant \\
\hline bilabial & $\mathrm{p}, \mathrm{b}$ & & & $\mathrm{m}$ & $(\mathrm{w})$ \\
\hline labiodental & & & $\mathrm{f}, \mathrm{v}$ & & \\
\hline dental & & & $\theta, \mathrm{d}$ & & \\
\hline $\begin{array}{c}\text { alveolar } \\
\text { post- } \\
\text { alveolar }\end{array}$ & $\mathrm{t}, \mathrm{d}$ & & $\mathrm{s}, \mathrm{z}$ & $\mathrm{n}$ & $\mathrm{I}$ \\
\hline $\begin{array}{c}\text { palato- } \\
\text { alveolar }\end{array}$ & & $\mathrm{t} \int, \mathrm{d} 3$ & $\int, 3$ & & $\mathrm{r}$ \\
\hline palatal & & & & & $\mathrm{j}$ \\
\hline velar & $\mathrm{k}, \mathrm{g}$ & & & $\mathrm{n}$ & $\mathrm{w}$ \\
\hline glottal & & & $\mathrm{h}$ & & \\
\hline
\end{tabular}


There are several mismatches between the sound systems of English and the sound systems of Arabic. Language use in Egypt is considered as a classic example of diglossia, a situation in which one dialect or language is used in formal or written domains and a second dialect or language is used largely in informal or spoken domains. The two varieties used in Egypt are referred to respectively as Modern Standard Arabic (MSA) and Egyptian colloquial Arabic, with differences on all language levels, including phonology (Warschauer, El Said \& Zohry, 2006). Dialectal variations in phonology are also evident in Arabic, especially in colloquial varieties. It is important to recognize this when assessing an Arabic speaker.

Both the phonological structure and phonetic characteristics of a speaker's native language influence their pronunciation of sounds in a foreign language learned in adulthood (Flege \& Port, 1981), and thus probably his/her transcription of this foreign language. When learners have trouble in perceiving the sounds which do not exist in their native language, they tend to find the nearest equivalents to substitute those new sounds. The connection between students' transcription skills and pronunciation has not been thoroughly researched, although some research suggests that there is a connection between pronunciation and productive transcriptions (Pelttari, 2015). Lintunen (2004) also confirmed this finding through a questionnaire administered to first year university students.

Amer (2010) highlighted a number of differences between English and Arabic consonant inventory resulting in pronunciation difficulties for 
Arab learners of English, the most important of which are:

1. /p/ does not occur in Arabic as a phoneme except in loan words. Arab learners usually have difficulty with English contrasts such as /pæn/ "pan" and /bæn/ "ban", for instance.

2. Although they occur in standard Arabic, $/ \theta /$ and /ð/ do not usually occur in dialectal Arabic. Instead /s/and /z/ are used respectively.

3. $/ \mathrm{t} /$ is replaced by $/ \mathrm{s} /$ especially in initial position.

4. / $\mathrm{n} /$ occurs in Arabic as an allophone of $/ \mathrm{n} / \mathrm{but}$ is not a separate phoneme.

5. Standard Arabic and some other dialects use /d3/ instead of /3/ and some other dialects, especially Egyptian use /g/. The choice of one form or another depends on the kind of dialect used. This causes some difficulty in the production of the English / $3 /$ which is often replaced by $/ d_{3} /$. Because the contrast between $/ d_{3} /$ and $/ 3 /$ in Arabic is not phonemic, i.e., does not affect meaning.

Bayoumi (2013) also reported the most common errors by Egyptian speakers in English consonants as summarized in the following table (see also Al-Jarf, 2011; Alfehaid, 2015; Hago \& Khan, 2015):

Table 2: Common pronunciation errors by Egyptian learners of English (Bayoumi, 2013)

\begin{tabular}{|c|c|c|c|}
\hline Consonant & Replaced with & Consonant & Replaced with \\
\hline$/ \mathrm{t} /$ & /d/ & $/ 3 /$ & $/ \mathrm{J} /$ \\
\hline$/ p /$ & /b/ & $/ \mathrm{t} J /$ & $/ \mathrm{J} /$ or $/ \mathrm{t} /$ \\
\hline$/ \mathrm{v} /$ & $/ f /$ & $/ d_{3} /$ & $\begin{array}{l}\text { /3/ especially in } \\
\text { initial position }\end{array}$ \\
\hline /ð/ & $|z|$ & $/ \mathrm{y} /$ & $\begin{array}{l}\text { /nk/ or /ng/ } \\
\text { especially in final }\end{array}$ \\
\hline
\end{tabular}




\begin{tabular}{|c|c|c|}
\hline & & position \\
\hline$|\theta|$ & $\mid \mathrm{s} /$ & \\
\hline
\end{tabular}

The present study hence aims to examine the phonemic transcription of 30 English words provided by a number of 60 Egyptian learners studying an introductory phonetics course at undergraduate level. It attempts to find out the errors made by students in transcribing English consonants. It also seeks to explain the reasons for these errors, with the aim of raising learners' awareness of them. The study touches upon the deeper underlying structures involved in learning phonetic transcription. Identifying the most frequent errors in phonemic transcription by Egyptian learners of English can help place more emphasis on them in teaching, thus helping the learning process to be more successful.

\section{Review of the literature}

Error Analysis (EA) is a branch of Applied Linguistics that emerged in the sixties to highlight the fact that learner errors are not only due to the learner's native language, but also reflect universal strategies (Khansir, 2012). Richards (1971) defines the field of error analysis as "dealing with the differences between the way people learning a language speak and the way adult native speakers of the language use the language" (p. 1). Corder (1967) states that error analysis is important to the researcher, the teacher and to learners themselves. Errors serve as a good means of observing learners' strategy and the learning process.

EA is thus important in identifying areas of difficulty for learners in order to place special emphasis on them in the course of the teaching 
process. This may also help in developing error-based teaching material. Moreover, a high frequency of errors may entail the use of remedial programs. Error analysis also helps to shed light on individualized instruction, in case certain learners need help in particular areas or aspects (Huang, 2002).

Error analysis was motivated by the need for objective quantitative scores of learners' errors, as opposed to the previous method of contrastive analysis (CA) which relied primarily on linguistics description of dissimilarities between languages as a more reliable method of predicting learning difficulties (Huang, 2002).

Corder (1967) distinguished between an error and a mistake. The former is systematic and comes as a result of linguistic incompetence, whereas the latter is not systematic and may result from transient factors such as fatigue or slips of the tongue. According to the behaviorist theory, learners' errors occur due to interference from the first language (L1). Similarities between L1 and L2 contribute to positive transfer, whereas differences account for negative transfer (Jabeen, Kazemian \& Shahbaz, 2015). According to Corder (1967):

The major contribution of the linguist to language teaching was seen as an intensive contrastive study of the systems of the second language and the mothertongue of the learner; out of this would come an inventory of the areas of difficulty which the learner would encounter and the value of this inventory would be 
to direct the teacher's attention to these areas so that he might devote special care and emphasis in his teaching to the overcoming, or even avoiding, of these predicted difficulties (p. 162).

However, many mistakes in fact have no parallel in L1 (Khansir, 2012). It was thus later posited that errors are also triggered by other universal underlying structures, as well as by learners' recognition. Other causes of errors include overgeneralization, simplification, underuse, fossilization, lack of knowledge and interference. In other words, errors may be caused by contrastive differences, as well as by the structure of the target language itself (Huang, 2002). According to Richards (1971), many errors arise not from interlanguage or L1 interference but from intralanguage. He defines these as developmental errors reflecting the learner's competence at a particular stage of learning. These "reflect the general characteristics of rule learning, such as faulty generalization, incomplete application of rules, and failure to learn conditions under which rules apply" (Richards, 1971, pp. 5-6).

Error analysis is usually criticized, however, for focusing on errors and ignoring positive reinforcement, as well as the strategy of "avoidance". It also gives attention to a specific language and fails to capture language universals. Above all, overemphasis on errors can frustrate learners' motivation (Huang, 2002). 
According to Sönning (2013), efficient transcription requires three main skills: "(i) correct concept of the pronunciation of a word in isolation/context (ii) productive command of symbols (iii) knowledge of rules and regularities underlying pronunciation/transcription" (p. 1). He distinguished different types of errors in students' transcription resulting from transfer phenomena, developmental errors and mixing of the British and the American standard (hereafter RP and GA). He states that "less systematic errors are typically due to unknown lexemes or carelessness" and that in transcribing written texts, "orthography-induced errors usually reflect grapheme-phoneme transfer"(Sönning,2013,p. 1).

Several studies have been conducted on error analysis for Arabs studying English as a second language, targeting different language levels (see Ali, 2007). Some examined morphological errors (El-Saidat, 2012) or syntactic errors

(Faisal, 2013), while others mainly focused on writing (Zawahreh, 2012). A number of studies also undertook an error analysis of Arab and Egyptian learners' pronunciation using a transcription of their speech (Bayoumi, 2013; El-Zarka, 2013; Alfehaid , 2015; Hago \& Khan, 2015). However, an error analysis of the phonemic transcription produced by Egyptian learners of English themselves, rather than transcribed by the researcher, is still a fertile area of study.

\section{Sample and methodology}

A list of 30 individual words was given to a number of 60 first-year students of an introductory phonetics course in order to transcribe. The experiment was done on two stages, separated by a two-week interval in each of which the students were asked to transcribe 
15 words. The list of words was prepared in such a way to ensure covering all 24 English consonants. They included a total of 76 consonants (31 phonemes in list 1 and 45 in list 2). The list included both monosyllabic and disyllabic words to suit the level of students at this introductory stage. However, disyllabic words were introduced in the second stage (10 words). In general, the second list comprised more complex words in terms of number of syllables and consonant clusters. The list of words along with their transcription is found in table 3. Alternative transcription in both RP and GA are provided were applicable. For simplicity, phonemic or broad transcription was used rather than phonetic or narrow transcription (Roach, 1983). Stress marking was not required.

Table 3: The list of words in the two data sets

\begin{tabular}{|c|c|c|c|}
\hline \multicolumn{2}{|c|}{ List 1} & \multicolumn{2}{|c|}{ List 2} \\
\hline Word & Transcription & Word & Transcription \\
\hline 1. bike & /bark/ & 1. jeans & /dzi:nz/ \\
\hline 2. house & /haus/ & 2. sure & $/ \iint^{\prime} \partial /(R P) / \int \sigma r /$ \\
\hline 3. dog & /dpg/ (RP) & & (GA) \\
\hline & /da:g/ (G & 3. thrift & /Orrft/ \\
\hline 4. man & /mæn/ & 4. pledge & /pled3/ \\
\hline 5. boat & & 5. few & /fju:/ \\
\hline 6. door & $/ \mathrm{docot} / \mathrm{d}$ & 6. measure & /mezar/ (GA) \\
\hline & /do:r/ (GA) & 7. vessel & /vesəl/ \\
\hline 7. world & $\begin{array}{l}\text { /ws:ld/ (RP) } \\
\text { /ws:ld/ (GA) }\end{array}$ & $\begin{array}{l}\text { 8. easy } \\
\text { 9. bother }\end{array}$ & $\begin{array}{l}\text { /i:zi/ } \\
\text { /bpðə/ (RP) }\end{array}$ \\
\hline 8. switch & /switj/ & & /ba:むər/ (GA) \\
\hline 9. book & /bok/ & 10. morning & $\mathrm{g} / \mathrm{mo:nIy} /(\mathrm{RP})$ \\
\hline 10. bear & /beə/ (RP) & & /mo:rnin/ (GA) \\
\hline & /ber/ (GA) & 11. party & /pa:ti/ (RP) \\
\hline 11. beer & /biə/ (RP) & & /pa:rti/ (GA) \\
\hline & /bIr/ (G & 12. cheering & 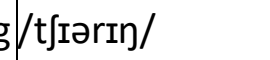 \\
\hline 12. boy & /bכor/ & 13. curser & /k3:sə/ (RP) \\
\hline
\end{tabular}




\begin{tabular}{|l|l|l|l|}
\hline 13. day & /der/ & & /k3:sər/ (GA) \\
14. run & /rın/ & 14. justice & /dz^stis/ \\
15. walk & /wo:k/ (RP) & 15. vision & /vizn/ \\
& /wa:k/ (GA) & & \\
\hline
\end{tabular}

The subjects of the present study are first year students at the College of Language and Communication (CLC) at the Arab Academy for Science, Technology and Maritime Transport (AASTMT). They study an introductory phonetics course which introduces them to English phonemes and broad phonetic transcription. The class meets twice a week for a 90-minute session. The course also touches upon suprasegmental features, including tone groups, stress and intonation. Students come from a variety of backgrounds, most of whom had English as their first foreign language in their secondary education, although with very little knowledge of English phonetics and phonology if any.

The research follows the procedure suggested by Corder (1974) for error analysis:

1. Selection: collecting samples of learners' language

2. Identification: determining the errors in the selected sample

3. Categorization: categorizing errors into groups

4. Explanation: accounting for the errors

5. Evaluation: interpreting the tables, graphs and conclusions

Transcription was administered in class and monitored by the researcher. The experiment was conducted on two stages, each consisting of 15 words and separated by a two-week interval during which students received further practice in transcription. 
Students did not have access to dictionaries or any other source of information while transcribing in order to measure their transcription skills without any interference. Transcription was carried out using the IPA revised to 2015 (The International Phonetic Association, 2015), the most widely used alphabet for phonetic transcription (Wells, 2006) and the one taught to the participants of the present study.

Students' transcription was examined with respect to errors in consonant transcription. Errors were identified by comparing their answers to the transcription of the sample words given in Cambridge Dictionary Online. It was chosen since it also uses IPA and provides RP and GA alternative pronunciations, which were both accepted in students' transcription.

A typology of errors was then created according to the four following categories (Corder, 1967):
1. Substitution
3. Addition
2. Omission
4. Ordering

The study attempts to answer the following questions:

1. Which errors involving consonants are recurrent in learners' transcription of English words?

2. Can these errors be accounted for systematically?

3. Do the errors correlate with common pronunciation errors of Egyptian learners of English?

\section{Data analysis}

By examining the two data sets, a typology of errors was created according to the four categories 
mentioned above. Creating an error typology was not a straightforward task, since some errors overlapped and some were not easy to categorize. Errors occurring in students' transcriptions can be categorized according to their origin (Sönning, 2013). Systematic errors include transfer phenomena, developmental errors and mixing of British and American standards. Less systematic errors are typically due to unknown lexemes or carelessness. In transcriptions of written texts, orthography-induced errors usually reflect grapheme-phoneme transfer or wrong inferences from ambiguous spellings. The relative frequency of an error was calculated as follows (Huang, 2002):

Relative frequency of occurrence of an error $=$ number of actual occurrences of an error number of possible occurrences of an error

\subsection{Substitution}

Substitution errors were the most frequent among the four error categories above, accounting for over $76 \%$ of the total number of errors identified in students' transcription. One of the most recurrent errors in students' transcription was using capital letters instead of small ones for consonant symbols. Almost $33 \%$ of the participants in the first data set and $17 \%$ in the second used at least one capitalized character for IPA consonant symbols. This was sometimes done consistently for all words by some learners and sometimes at random for one or a few words only. This error mostly occurred in initial position under the influence of orthography, but occurred also in very few instances with consonants in medial and final position. 
The substitution of small letters with capital ones may be regarded as a mere formal notation error that shows lack of knowledge of transcription conventions and reflects the influence of graphemephoneme transfer. This type of error does not reflect a pronunciation difficulty or an inherent problem with target language. Furthermore, it does not generally affect the intelligibility of the transcription, especially for characters whose capitalized version does not exist in IPA, such as " $B$ ", " $D$ " or " $M$ " (Quotations will be used instead of slashes for non-IPA characters). On the other hand, in cases where the capital alternative corresponds to another completely different IPA symbol, the intelligibility of the transcription was jeopardized. Cases in point were the symbols /R/, /N/ and /G/ which represent a uvular trill, nasal and plosive respectively.

Substitution errors also occurred in the transcription of other consonants as shown in table 4.

Table 4: Substitution errors

\begin{tabular}{|c|c|c|c|}
\hline Consonant & $\begin{array}{c}\text { Substituted } \\
\text { with }\end{array}$ & Consonant & $\begin{array}{c}\text { Substituted } \\
\text { with }\end{array}$ \\
\hline$/ \mathrm{s} /$ & $\begin{array}{c}\mid 3 /, / \mathrm{z} /, / \mathrm{k} / \\
/ \mathrm{c} /\end{array}$ & /z/ & $\begin{array}{c}\text { /s/ in "easy", } \\
\text { plural } \\
\text { morpheme, } \\
/ 3 /, / \text { / }\end{array}$ \\
\hline /k/ & $/ c /$ & /g/ & $/ 3 /$ \\
\hline$/ \mathrm{t} / /$ & $/ \int /$, 'ch' & $/ d /$ & $/ 3 /$ \\
\hline$/ d_{3} /$ & $\begin{array}{c}\text { /j/, } / \mathrm{g} /, \mathrm{,} / 3 /, \\
\mathrm{dg}^{\prime}\end{array}$ & $/ \theta /$ & /ð/ \\
\hline$/ \mathrm{h} /$ & 'ng' & /ð/ & $/ \mathrm{s} /, / 3 /$ \\
\hline$/ \mathrm{S} /$ & $\begin{array}{c}\text { /s/ in 'sure', } \\
/ \mathrm{t} \int /\end{array}$ & /j/ & $\begin{array}{c}\text { /ı/, /v/, /i:/, } \\
\text { /e/, /l/ }\end{array}$ \\
\hline
\end{tabular}


Some substitution errors coincided with phonemes which are commonly problematic to Egyptian learners of English, such as replacing the velar nasal with 'ng' under the influence of orthography, or substituting / $/ /$ for $/ \mathrm{t} /$ / in "cheering" or /3/ for /dz/ in "pledge" (which may also be regarded as an omission error). On the other hand, with the exception of notation errors mentioned above involving capitalization, no errors occurred in the transcription of the stops $/ \mathrm{p} /, / \mathrm{b} /$ and $/ \mathrm{t} /$, the fricatives /f/, /v/ and /h/or the nasal /m/. This does not coincide with the most common pronunciation problems faced by Egyptian learners of English involving bilabial stops and labiodentals fricatives. It is worth mentioning that the participants in the present study never replaced /p/ with /b/, / $\theta /$ with /s/ or /v/ with / $f /$ as usually happens in speaking Bayoumi (2013 - see section 1$)$.

The palatal semivowel displayed a high frequency of substitution errors, being replaced with four different vowels $/ I, v, i:$, e/, in addition to the lateral / $/$. This was followed by $/ \mathrm{d}_{3} /$ which was transcribed in four different ways, $/ \mathrm{j} /, / \mathrm{g} /, / 3 /$, and 'dg'.

Regarding alveolar fricatives, the plural morpheme ' $s$ ' was transcribed as /s/ instead of / $/$ / by $10 \%$ of the participants after voiced sounds, as in "jeans", despite introducing the relevant rule to students in class. Surprisingly, the consonant /s/ also a relatively high frequency of substitution errors, being replaced with four different alternatives $(/ 3 /, / z /, / k /$, and $/ c / /$, although this is not usually reported as a problematic consonant where pronunciation is concerned. It was even sometimes transcribed as /k/ 
when spelt with a " $c$ " when students were not familiar with the correct pronunciation of a word (e.g., "justice").

It is interesting that no substitution errors occurred in the first data set in $/ \mathrm{k} /$ although it included 3 instances, whereas $10 \%$ of participants transcribed $/ \mathrm{k} / \mathrm{as} / \mathrm{c} /$ in the second data set (which happens to be the IPA symbol for a palatal plosive not existing in English). The reason apparently is that all instances of this phoneme in the first set where spelt with ' $k$ ', as opposed to the word 'curser' in the second list.

Figure 1: The most frequently substituted consonants

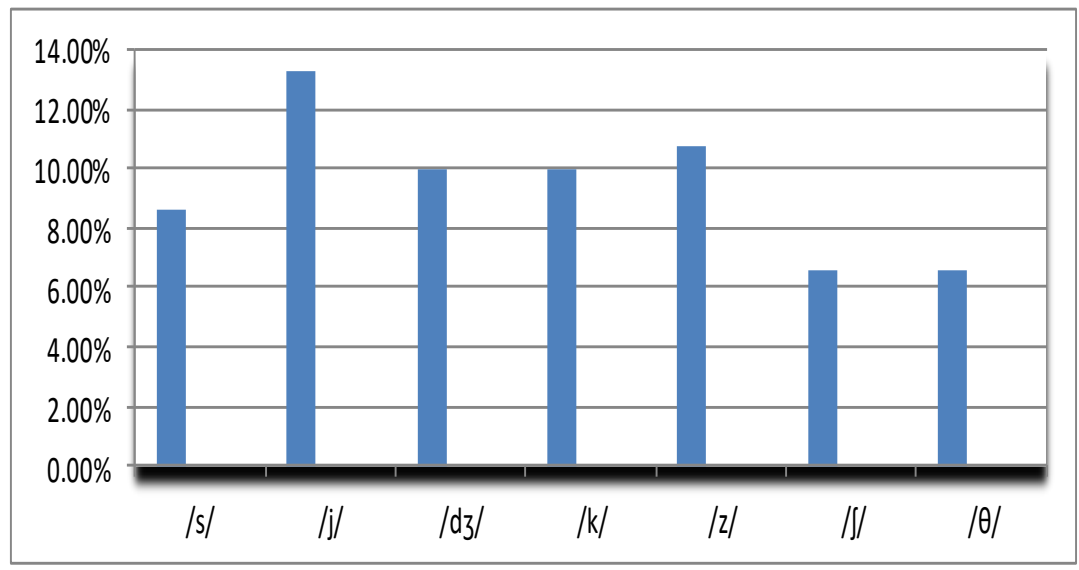

Substitution errors were most obvious on the voicing dimension in particular. The voiceless dental was replaced with the voiced one in $7 \%$ of the cases and $/ \mathrm{s} /$ and $/ \mathrm{z} /$ were frequently substituted for each other. Some substitution errors were also made across place of articulation, especially between alveolar and palato-alveolar fricatives. On the other hand, no substitution errors were related to manner of articulation (except between fricatives and affricates by omitting or adding the stop preceding the fricative). 
Sometimes there was no clear reason or explanation for an error, such as replacing /d/ with /3/ or /b/ with /d/ for no apparent reason. Such unsystematic errors may simply be due to carelessness or lack of attention. Moreover, /s/ was used unexpectedly to replace the voiced dental fricative not the voiceless one contrary to the common error in Egyptian learners spoken English.

\subsection{Omission}

The consonants most frequently deleted in students' transcription were $/ \mathrm{n} /, \mathrm{I} /$ and $/ \mathrm{r} /$, followed by $/ \mathrm{j} /$ as shown in the figure 2 .

Figure 2: The most frequently omitted consonants

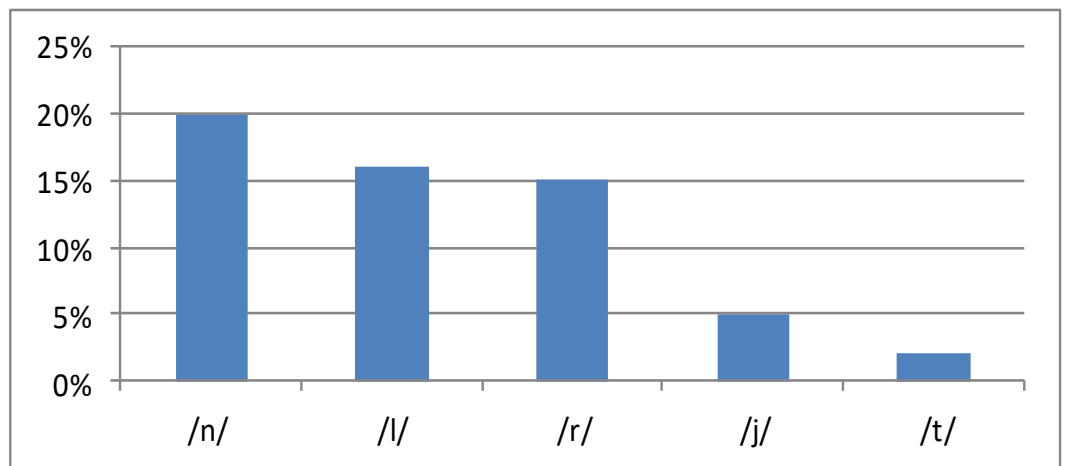

The nasal $/ \mathrm{n} /$ was deleted in syllables containing a velar nasal, in 'morning' by $20 \%$ of the participants. The lateral consonant /I/ was also omitted from the transcription of "world" by $16 \%$ of the participants, suggesting a reduction of a three-consonant cluster at the end of this world. This was done both by those who provided the RP transcription as well as those who opted for the American one.

The $/ r$ / was deleted by $15 \%$ of the participants due to the overgeneralization of $/ r /$ dropping in RP in the word "cheering", although the $/ r$ / was followed by 
a vowel rather than a consonant. However, no omission occurred in other positions for this phoneme.

Similarly, the palatal / $\mathrm{j} /$ was also deleted in $5 \%$ of the cases due to overgeneralization of the GA yoddropping rule. It was also found that $2 \%$ of the students transcribed the palato-alveolar affricate as the fricative $/ \mathrm{s} /$ instead of $/ \mathrm{t} /$ / by eliminating the $/ \mathrm{t} /$.

It is interesting that omission errors frequently involved approximants or semi-vowels which are consonants whose articulation involves minimum obstruction of the air stream, unlike plosives or fricatives, for instance which require major interference of the air stream.

Some omission errors were unsystematic; consonants were skipped in students' transcription for no clear reason, e.g. some students left out the $/ \mathrm{w} /$ in 'switch' (medial position) and the /g/ in ' $\mathrm{dog}^{\prime}, \mathrm{s} / \mathrm{in}$ 'house' and the /t/ in 'boat' (final position). The /s/ was also deleted for no clear reason in only $1 \%$ of the cases. Again such unsystematic errors may reflect carelessness rather than lack of knowledge. No such deletions were encountered in initial position.

\subsection{Addition}

Addition errors were rather rare in the sample and were mainly caused by the influence of orthography. This includes consonant doubling of /s/ in words such as "vessel". Silent letters were sometimes also transcribed probably due to the effect of spelling rather than unfamiliarity with the pronunciation of a given word. A case in point is that $9 \%$ of the participants inserted an $/ I /$ in the transcription of the word "walk". 
Some unsystematic addition errors were found, such as adding an /s/ or / $\mathrm{t} /$ preceding $/ \mathrm{J} /$ or inserting an $/ n /$ after the $/ r /$ in "cheering". Similarly, $5 \%$ of the participants doubled the /t/ in "switch" for no apparent reason.

Just as omission errors involved $/ r /$ deleting due to over-generalizing $/ r$ / dropping in RP, some addition errors also occurred due to inserting an $/ r /$ after RP schwa diphthongs, which was done by almost $42 \%$ of the participants in "bear" and 18\% in "beer".

\subsection{Ordering}

No ordering errors were encountered in the two data sets. Despite all the above errors, all phonemes were transcribed in the appropriate order.

\section{Findings and discussion}

The table below sums up the number of errors identified in the two data sets. The highest number of errors in the sample were substitution errors, followed by omission. Replacing IPA symbols with their capital letter counterparts was found to be the most frequent among substitution errors, and the consonants most frequently replaced by other phonemes were /j/, /z/, / $\mathrm{d} 3 /$ and $/ \mathrm{k} /$. On the other hand, consonants which were deleted the most were $/ \mathrm{n} /, / \mathrm{l} /, / \mathrm{r} /$ and $/ \mathrm{j} /$. Addition errors were rather few, whereas no errors were encountered involving ordering in the sample. The two data sets displayed an almost even distribution of the four error types, apart from a relative decrease of substitution errors against omission errors in the second sample (see figure 3). 
Figure 3: Types of errors in the two data sets
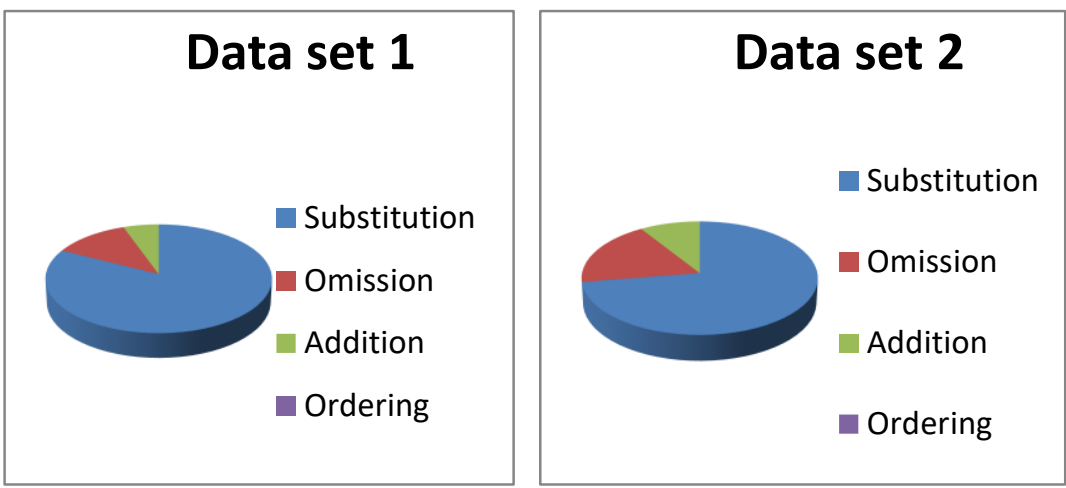

The total number of errors in the second data set was higher than the first (92 in the first compared to 135 in the second - see table 4), although students had received more training and practice in transcription. Moreover, all error types were more frequent in the first data set than in the second, except ordering of which no instances were found in neither sets. This could be due to the presence of phonemes in the second set that had not been introduced in the first, such as dentals and palatoalveolar, which are usually problematic for Egyptian learners of English. Another possible reason could be the introduction of more complex two-syllable words in the second data set, as the first only included monosyllabic words.

Table 4: Number of errors in the two data sets

\begin{tabular}{|l|c|c|c|c|c|}
\hline & Substitution & Omission & Addition & Ordering & Total \\
\hline $\begin{array}{l}\text { First } \\
\text { data set }\end{array}$ & 76 & 11 & 5 & 0 & 92 \\
\hline
\end{tabular}




\begin{tabular}{|l|c|c|c|c|c|}
\hline $\begin{array}{l}\text { Second } \\
\text { data set }\end{array}$ & 98 & 25 & 12 & 0 & 135 \\
\hline Total & 174 & 36 & 17 & 0 & 227 \\
\hline
\end{tabular}

The results also suggest that transcription errors do not always coincide with commonly reported pronunciation difficulties faced by Egyptian learners of English. Contrary to expectation, /p, b/ and /f, v/ were not confused with each other and $/ \theta, \delta /$ were not replaced with /s, z/ but were rather substituted for each other or replaced with other consonants, such as /s/ and /3/. However, palato-alveolar consonants were the only case with a high frequency of errors coinciding with pronunciation difficulties, with voiced and voiceless counterparts being substituted for each other.

Some errors were either due to lack of experience in transcription or were related to grapheme-phoneme transfer. Still a number of errors correlated with phonemes which are usually problematic to Egyptian learners of English. This leaves us with three main types of errors encountered in students' transcription:

- Notation errors resulting from lack of transcription knowledge or practice

- Errors resulting from the influence of orthography (grapheme-phoneme transfer)

- Overgeneralization of rules (e.g., / $r$ / dropping in RP or yod-dropping in GA)

- Errors related to problematic phonemes in L2

Several errors occurred due to graphemephoneme transfer, which involved either substitution or addition: 
- Replacing small letters with capital ones, particularly in initial position

- Copying orthography rather than relying on pronunciation

- Transcribing silent letters

- Consonant doubling

The findings, therefore, reveal that transcription errors do not always coincide with common pronunciation difficulties. Rather, most of them stem from grapheme-phoneme transfer and lack of transcription knowledge. Phonemes which have never been reported to represent difficulties to language learners have displayed a high frequency of errors. Cases in point are $/ \mathrm{z} /, \mathrm{j} /, \mathrm{s} / \mathrm{s} / \mathrm{h} /$ and $/ \mathrm{l} /$. On the other hand, phonemes often representing pronunciation difficulties for Egyptian learners of English, such as bilabial stops and labiodentals fricatives received error-free transcription.

It may hence be posited that transcription errors, in line with language errors in general, are not only triggered by L1 interference as highlighted by Richards (1971), but also arise from developmental factors, including overgeneralization, ignorance of rules, as well as mutual interference of items in the target language itself. Furthermore, the findings confirm Sönning's (2013) view that less systematic errors usually occur with unfamiliar words or due to learners' carelessness.

\section{Conclusion}

The identification of the most recurrent transcription errors can serve as an excellent basis for preparing instructional materials, course planning and 
developing actual classroom techniques. In this way, teachers can be made aware of difficult areas or common pitfalls for their students and devote special care and emphasis to them.

The present research examined the phonemic transcription of 30 English words provided by a number of 60 Egyptian learners studying an introductory phonetics course at undergraduate level. It attempted to find out the errors made by students in transcribing English consonants. The errors were classified and analyzed with the aim of raising learners' awareness of them.

It is worth noting that the scope of the study encompassed only transcription errors, since students' actual pronunciation errors were not investigated. In fact, the findings of the study show that transcription errors do not always coincide with pronunciation difficulties commonly faced by Egyptian speakers of English as reported in the literature. Since transcription errors were mainly found to be developmental errors, practice and remedial exercises and drills should focus on the following areas:

- Dedicating sessions especially for consonant transcription rather than complete words. It is important that students master consonant transcription as a first stage since vowels bring a further host of difficulties.

- Transcription conventions and emphasis on the use of IPA consonant symbols without the slightest alteration in their form.

- Neutralizing the effect of orthography and stressing that transcription is mainly concerned with sounds rather than the spelling of words. 
- Placing more emphasis on the transcription of consonants that have unexpectedly proven problematic in the above experiment such as $/ \mathrm{s} /, / \mathrm{z} /, / \mathrm{j} /$ and $/ \mathrm{d}_{3} /$ in different positions.

The findings of the present study beg for more in-depth work in the following research areas:

- Similar studies should target errors in vowel transcription, which are expected to be more complicated due to the vast discrepancy between English vowels (20) and Arabic vowels (only 6).

- Further studies should be conducted on teaching methods designed to eliminate the errors reported by the present study, as well as to improve students' transcription skills in general.

- More quantitative studies are required to measure the effectiveness of various methods and materials used for transcription teaching and training on different groups of students and their development across the duration of studying.

- Further studies may also tackle errors made by Egyptian phonetics students in terms of other more advanced suprasegmental features, such as stress assignment, syllable division and intonation. 


\section{References}

1. Alfehaid, M. (2015, Oct.). Pronunciation problems Arab speakers encounter while learning English. International Journal of Scientific and Engineering Research, 6(10). Retrieved from http://www.ijser.org/researchpaper/Pronunciati on-Problems-Arab-Speakers-Encounter-WhileLearning-English.pdf

2. Ali, N. A. (2007). Some linguistic problems facing Arab learners of English. Adab Al-Rafidayn. (48). Retrieved from

\section{http://www.iasj.net/iasj?func=fulltext\&ald=33586}

3. Al-Jarf, R. (2001). Contrastive phonology. Retrieved from

https://uogenglish.files.wordpress.com/2011/07/contra stive-phonology-transparencies.pdf

4. Al-Saidat, E. (2012). Acquisition of the inflectional morphology of English as a foreign language: An error analysis approach. The Buckingham Journal of Language and Linguistics.(5).

doi: http://dx.doi.org/10.5750/bjll.v5i0.211 
5. Amer, W. M. (2010). An investigation into the differences between English and Arabic consonant and vowel sounds: A contrastive study with pedagogical implications. Retrieved from.

http://site.iugaza.edu.ps/wamer/files/2010/02/ An-investigation-into-the-Differences-betweenEnglish-and-Arabic-Consonant-and-VowelSounds-review.pdf

6. Atkielski, A. (2005, Dec.). Using phonetic transcription in class. Retrieved from http://digilander.libero.it/mgtund/Phonetics\%20\%20Using\%20Phonetic\%20Transcription\%20in\%20Class. pdf

7. Bayoumi, A. (2013). Common pronunciation errors in the speech of undergraduate Egyptian students at Ain Shams University and ways of dealing with them. Retrieved from https://languagers.wordpress.com/2013/09/13/ common-pronunciation-errors-in-the-speech-ofundergraduate-egyptian-students-at-ain-shamsuniversity-and-ways-of-dealing-with-them/

8. Cambridge Dictionaries Online (2016, May). Retrieved from http://dictionary.cambridge.org/

9. Corder, S. P. (1967, Nov.). The significance of learner's errors. International Review of Applied Linguistics in Language Teaching.V(4). Retrieved from http://files.eric.ed.gov/fulltext/ED019903.pdf 
10.Corder, S. P. (1974). Error analysis. In J. P. B. Allen \& P. Corder (Eds.). Techniques in Applied Linguistics (The Edinburgh Course in Applied Linguistics). 3. (pp. 122-131). London: Oxford University Press.

11.Cruttenden, A. (2014). Gimson's pronunciation of English. (8 ${ }^{\text {th }}$ ed.). New York: Routledge.

12. El-Zarka, A. M. (2013, Oct.). The pronunciation errors of L1 Arabic learners of L2 English: The role of Modern Standard Arabic and vernacular dialects transfer. MA dissertation. The British University in Dubai. Retrieved from http://bspace.buid.ac.ae/bitstream/1234/664/1/90 087.pdf

13. Faisal, W. M. (2013). Syntactic errors made by students of Department of Educational and Psychological Sciences. Journal of Babel University for Human Sciences. 21(2). (pp. 456-470). Retrieved from

http://uobjournal.com/papers/uobj_paper_2014_4 84421.pdf

14. Flege, J. E. \& Port, R. (1981). Cross-language phonetic interference: Arabic to English. Language and speech, 24(2). Retrieved from http://jimflege.com/files/Flege_Port_phonetic_inte rference_L_S_1981.pdf 
15. Hago, O. E. \& Khan, W. A. (2015, Oct.) The pronunciation problems faced by Saudi EFL learners at secondary schools. Education and Linguistics Research. 1(2). (pp. 85-99). doi:10.5296/10.5296/elr.v1i2.7783

16. Huang, J. (2002). Error analysis in English teaching: A review of studies. Retrieved from

http://lib.csghs.tp.edu.tw/\%E4\%B8\%AD\%E5\%B1\%B 1\%Е5\%A5\%B3\%Е9\%AB\%98\%E5\%AD\%B8\%E5\%A0\%B 1\%E7\%AC\%AC\%E4\%BA\%8C\%E6\%9C\%9F/03ERROR\% 20ANALYSIS.pdf

17. Jabeen, A., Kazemian, B. \& Shahbaz, M. (2015, Sept.). The role of error analysis in teaching and learning of second and foreign language. Education and Linguistics Research. 1(2). (pp. 52-62). doi:10.5296/elr.v1i1.8189

18. Khansir, A. A. (2012, May). Error analysis and second language acquisition. Theory and practice in language studies. 2(5). (pp. 1027-1032). Retrieved from

http://ojs.academypublisher.com/index.php/tpls/ar ticle/view/tpls020510271032

19. Kuutti, N. (2009, May). The use of phonemic transcription as a teaching method and its effects of language learning outcomes. MA Dissertation. Retrieved from https://jyx.jyu.fi/dspace/bitstream/handle/123456789/2 0115/Niina_Kuutti\%20\%20BA\%20thesis.pdf?sequence $=1$ 
20. Lintunen, P. (2004). Pronunciation and phonemic transcription: A study of advanced Finnish learners of English. Retrieved from https://www.ucl.ac.uk/pals/study/cpd/cpdcourses/ptlc/proceedings_2005/ptlcp30

21. Lintunen, P. (2005). Phonemic transcription and its effect on learning. Retrieved from https://www.ucl.ac.uk/pals/study/cpd/cpdcourses/ptlc/proceedings_2005/ptlcp30

22. Pelttari, J. (2015). Use of phonemic transcription as a teaching method in Finnish schools. (MA Dissertation, Faculty of Humanities, University of Oulu). Retrieved from http://jultika.oulu.fi/files/nbnfioulu201602031104.pdf

23. Richards, J.C. (1971). A non- contrastive approach to error analysis. Journal of ELT. 25, (pp. 204-219). Retrieved from http://files.eric.ed.gov/fulltext/ED037721.pdf

24. Roach, P. (1983). English phonetics and phonology: A practical course. UK: Cambridge University Press.

25. Sönning, L. (2013). Scrabble yourself to success: Methods in teaching transcription. Proceedings of the Phonetics Teaching and Learning Conference, J. Przedlacka \& and J. Maidment (Eds.). (pp. 83-86). Retrieved from http://wa.amu.edu.pl/kdk/sites/default/files/pr oceedings_2013.pdf 
26. The International Phonetic Association (2015). The International Phonetic Alphabet (revised to 2015). Retrieved from https://www.internationalphoneticassociation.o rg/sites/default/files/IPA_Kiel_2015.pdf

27.Warschauer, M., El Said, G. R. \& Zohry, A. G. (2006, June). Language choice online: Globalization and identity in Egypt. Journal of Computer-mediated Communication. 7(4). DOI: 10.1111/j.1083-6101.2002.tb00157.x

28.Wells, J. C. (2006). Phonetic transcription and analysis. In Encyclopedia of Language and Linguistics. Retrieved from

http://www.phon.ucl.ac.uk/home/wells/transcri ption-ELL.pdf.

29. Zawahreh, F. A. (2012, April). Applied error analysis of written production of English essays of tenth grade students in Ajloun Schools, Jordan. International Journal of Learning \& Development. 2(2). doi:10.5296/ijld.v2i2.1680 